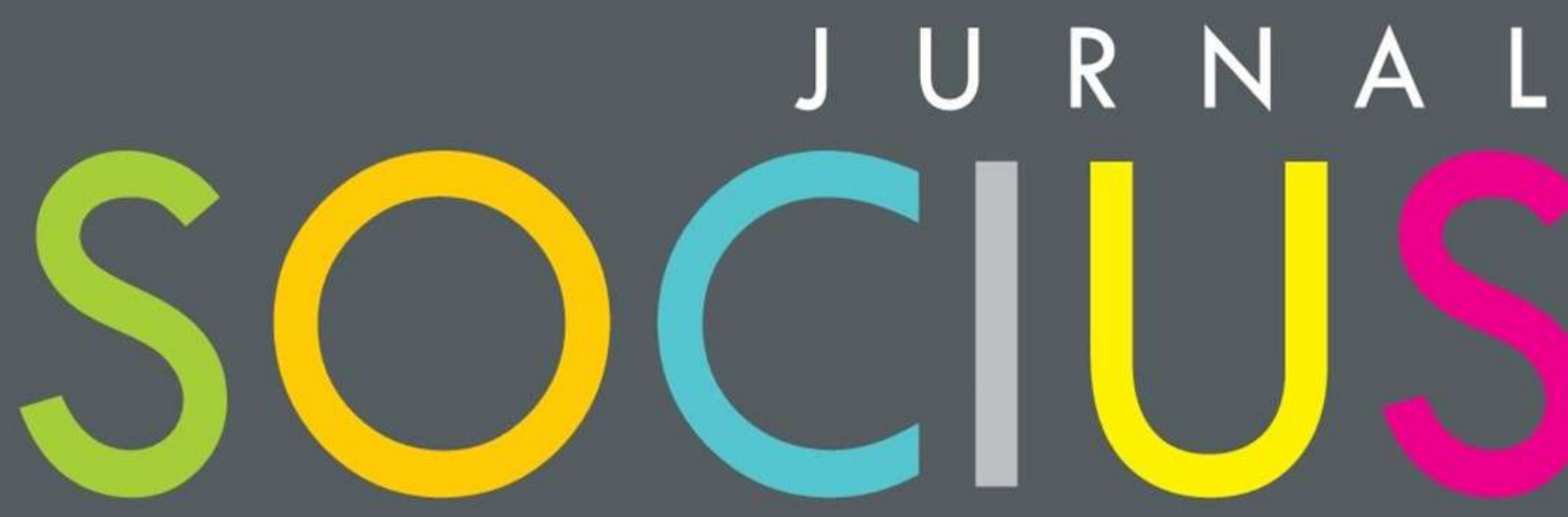

Journal of Sociology Research and Education

DITERBITKAN OLEH :

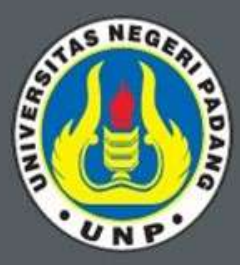

LABOR JURUSAN SOSIOLOGI FAKULTAS ILMU SOSIAL UNIVERSITAS NEGERI PADANG

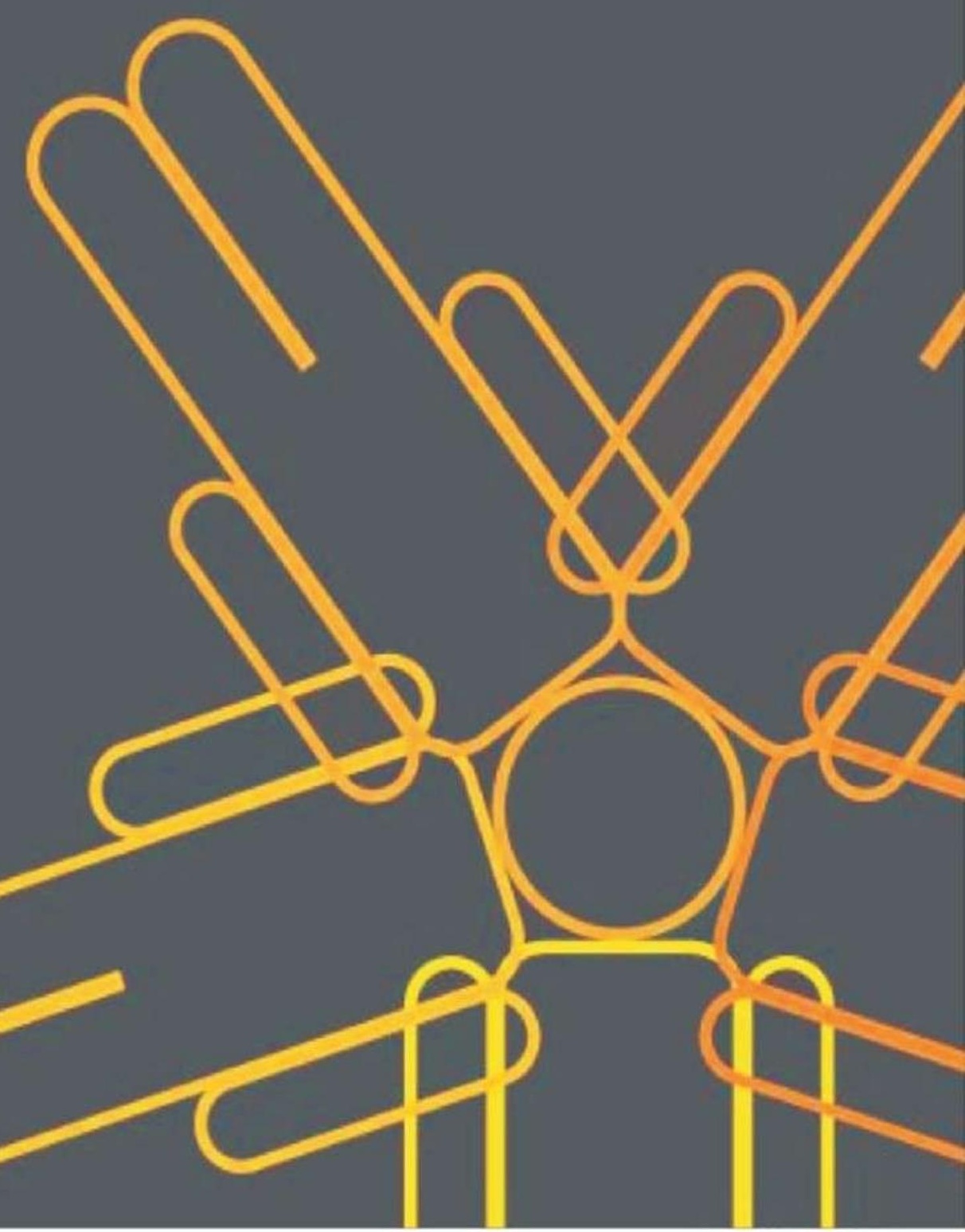




\section{SOCIUS}

Vol. 6, No.2, Th. 2019

ISSN : 2356-4180 (cetak)

2442-8663 (online)

\begin{tabular}{|c|c|}
\hline $\begin{array}{c}\text { REDAKSI } \\
\text { JURNAL SOCIUS }\end{array}$ & DAFTAR ISI \\
\hline $\begin{array}{c}\text { Editor in Chief : } \\
\text { Selinaswati } \\
\text { Managing Editor : } \\
\text { Erda Fitriani } \\
\text { Editorial Board: } \\
\text { Eka Vidya Putra } \\
\text { Desy Mardiah } \\
\text { Ike Sylvia } \\
\text { Erianjoni } \\
\text { Mohammad Isa Gautama } \\
\text { Reno Fernandes }\end{array}$ & $\begin{array}{c}\text { Mutia Kahana, Junaidi } \\
\text { Pengaruh Penerapan Model Konsiderasi Terhadap Pembentukan } \\
\text { Sikap Siswa dalam Pembelajaran Sosiologi di Kelas XI IPS SMA } \\
\text { Adabiah Padang } \\
\text { Halaman 62-69 } \\
\text { Reno Fernandes } \\
\text { Revolusi 4.0 } \\
\text { Halaman } 70-80\end{array}$ \\
\hline $\begin{array}{c}\text { Reviewer: } \\
\text { Rebecca Fanany } \\
\text { Elly Malihah } \\
\text { (Deakin University , } \\
\text { (Universitas Pendidikan Indonesia, Indonesia) } \\
\text { Nur Hidayat Sardini } \\
\text { (Universitas Diponegoro, Indonesia) } \\
\text { Ubedilah Badrun } \\
\text { ( Universitas Negeri Jakarta, Indonesia) } \\
\text { Moh. Yasir Alimi } \\
\text { (Universitas Negeri Semarang, Indonesia) } \\
\text { Ferdinand Kerebungu } \\
\text { (Universitas Negeri Menado, Indonesia) } \\
\text { Jendrius } \\
\text { (Universitas Andalas, Indonesia) } \\
\text { Lucky Zamzami } \\
\text { (Universitas Andalas, Indonesia) } \\
\text { Adri Febrianto } \\
\text { (Universitas Negeri Padang, Indonesia) } \\
\text { Ikhwan } \\
\text { (Universitas Negeri Padang, Indonesia) } \\
\text { Aisiah } \\
\text { (Universitas Negeri Padang, Indonesia) } \\
\text { Junaidi Indrawadi } \\
\text { (Universitas Negeri Padang, Indonesia) } \\
\text { Sadri Chaniago } \\
\text { (Universitas Andalas, Indonesia) }\end{array}$ & $\begin{array}{c}\text { Andreas Dego, Yoseph D.A. Santie, Sem Deehop, Ferdinand } \\
\text { Kerebungu } \\
\text { Analisis Kompetensi Pedagogik Guru IPS di SMP Negeri } 1 \text { Kabupaten } \\
\text { Pulau Morotai } \\
\text { Halaman } 81-89 \\
\text { Yuyut Chandra, Aidinil Zetra, Ria Ariyany } \\
\text { LKAAM Kota Solok) } \\
\text { Halaman 90-102 } \\
\text { Demokrasi Deliberatif Masyarakat Minangkabau (Studi Kasus: } \\
\text { Ike Sylvia, Syafri Anwar, Khairani } \\
\text { Pengembangan Instrumen Penilaian Autentik Berbasis Pendekatan } \\
\text { Authentic Inquiry Learning Pada Mata Pelajaran Sosiologi di Sekolah } \\
\text { Menengah Atas } \\
\text { Halaman 103-120 } \\
\text { Pawennari Hijjang, Lia Amelia } \\
\text { Assajingeng: Politik Kekerabatan di Pilkada Kabupaten Bone (Analisis } \\
\text { Antropologi Politik) } \\
\text { Halaman 121-134 }\end{array}$ \\
\hline $\begin{array}{c}\text { Layout Editor : } \\
\text { Rhavy Ferdyan, S.Pd. } \\
\text { Technical Support: } \\
\text { Rudi Mahesa, A.Md. } \\
\text { Alamat Redaksi: } \\
\text { Jurusan Sosiologi FIS UNP } \\
\text { Jl. Prof.Dr.Hamka } \\
\text { Kampus UNP Air Tawar } \\
\text { e-mail: sosan@ fis.unp.ac.id } \\
\text { Penerbit } \\
\text { Labor Jurusan Sosiologi } \\
\text { Universitas Negeri Padang }\end{array}$ & \\
\hline
\end{tabular}




\title{
Demokrasi Deliberatif Masyarakat Minangkabau (Studi Kasus: LKAAM Kota Solok)
}

\author{
Yuyut Chandra ${ }^{1}$, Aidinil Zetra ${ }^{2}$, Ria Ariany ${ }^{3}$ \\ 1,2,3 Universitas Andalas \\ Email: yuyutchandra@gmail.com, aidinil@yahoo.co.id, uja.ujaku@gmail.com
}

\begin{abstract}
Abstrak
Demokrasi deliberatif berusaha mengubah kebijakan pemerintah melalui diskusi yang argumentatif. Lembaga Kerapatan Adat Alam Minangkabau (LKAAM) Kota Solok merupakan intitusi yang berusaha aktif membantu pemerintah Kota Solok dalam merumuskan kebijakan publik melalui diskusi yang argumentatif. Penelitian ini mendesripsikan bagaimana pelaksanaan prinsip demokrasi deliberatif masyarakat Minangkabau. Penelitian ini menggunakan pendekatan kualitatif untuk melihat proses pelaksanaan prinsip demokrasi deliberatif. Proses pelaksanaan prinsip demokrasi deliberatif LKAAM Kota Solok merupakan kehendak dari masyarakat adat yang memberikan kewenangan kepada pemimpin adat untuk menjembatani kepentingan masyarakat dengan pemeritah dan sebaliknya. Informasi dari masyarakat diproses dalam kesepekatan bersama (musyawarah rutin) dan kemudian disampaikan kepada pemerintah. LKAAM Kota Solok juga berperan dalam mengkritisi kebijakan yang dikeluarkan oleh Pemerintah Kota Solok.
\end{abstract}

Kata Kunci: Demokrasi, Demokrasi Deliberatif, LKAAM, Kebijakan Publik

\section{Abstract}

Deliberative democracy seeks to change government policy through argumentative discussion and joint evaluation among citizens. Lembaga Kerapatan Adat Alam Minangkabau (LKAAM) of Solok City is an institution that seeks to actively assist the Solok City government in formulating public policy through argumentative discussions. This study describes how the implementation of the deliberative democratic principles of the Minangkabau people. This study uses a qualitative approach to see the process of implementing the principle of deliberative democracy. The process of implementing of deliberative democracy LKAAM Solok City is the will of the indigenous people who give authority to the traditional leader to bridge the interests of the community with the government and vice versa. Information from the public processed in a consensus agreement and later passed on to the government. Solok City LKAAM also played a role in criticizing the policies issued by the Solok City Government. Keywords: Democracy, Deliberative Democracy, LKAAM, Public Policy

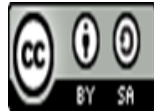

Received: October 14, 2019

Revised: December 30, 2019 Available Online: December 31, 2019 


\section{Pendahuluan}

Menurut beberapa ahli, demokrasi deliberatif adalah proses perumusan kebijakan publik yang dilakukan melalui musyawarah antar warga negara yang bebas dan egaliter. Demokrasi deliberatif berusaha merubah kebijakan pemerintah melalui diskusi yang argumentatif, penilaian bersama di antara warga masyarakat (Chambers, 2003; Cunningham, 2002; Elster, 1998; Gutmann dan Thompson, 1996). Berbeda dengan teori demokrasi liberal yang menggunakan pemungutan suara sebagai institusi utama untuk mengidentifikasi dan menggabungkan preferensi masyarakat, demokrasi deliberatif lebih menonjolkan musyawarah di kalangan warga masyarakat sebagai sumber legitimasi pembuatan keputusan atau undangundang (Mansbridge, 1980; Young, 2000).

Konsep demokrasi deliberatif lebih banyak mengacu pada pengertian baru di Barat, khususnya di Amerika Serikat, ketika semakin banyak ilmuwan mengemukakan adanya gejala "defisit demokrasi" dan "defisit kewarganegaraan" (Macedo, 1999). Menurut Habermas demokrasi harus mempunyai variable deliberatif didalamnya, dimana kebijakan publik harus disahkan melalui diskursus atau diskusi publik. Artinya demokrasi deliberatif menuntut partisipasi pada level tinggi dari masyarakat sehingga menciptakan hukum yang sah (Haliim. 2016).

Di Indonesia demokrasi deliberatif secara tradisional telah lama dianut, salah satunya adalah masyarakat Minangkabau. Dalam adat Minangkabau musyawarah mufakat merupakan kata kunci dalam sistem demokrasinya. Begitu pentingnya musyawarah dan mufakat dalam kebudayaan Minangkabau sehingga pepatah adat mengatakan: lamak samba dikunyah-kunyah, lamak kato dipakatokan, elok kato di mufakat, kato surang dibuleki, kato basamo dipaiyokan, bulek aia ka pambuluah, bulek kato dek mufakat (enak lauk dikunyah-kunyak, enak kata diperbincangkan, elok kata dimufakat, kata seorang dibulati, kata bersama dimusyawarahkan, bulat air karena pembuluh, bulat kata karena mufakat) (Naim, 1987).

Meskipun seorang pemimpin dalam adat Minangkabau memiliki kekuasaan yang besar dalam mengatur kehidupan sukunya, tetapi dalam bertindak ia dituntut untuk melakukan musyawarah lebih dahulu. Untuk itu adat Minangkabau menentukan: "kamanakan barajo ka mamak, mamak barajo ka Panghulu, Panghulu barajo ka mufakat, mufakat barajo ka alua jo patuik" (kemenakan belajar kepada mamak, mamak belajar kepada Penghulu, Penghulu belajar kepada mufakat, mufakat belajar kepada Alur dan Patut) (Nasroen, 1975). Namun dalam perkembangannya, nilai-nilai demokrasi di Minangkabau telah mengalami erosi. Diantaranya, penerapan sistem pemerintahan desa yang dipaksakan di Nagari dan penerapan demokrasi liberal (one man one vote), Perda yang mengatur tentang pemilihan Wali Nagari telah memusnahkan kelembagaan tradisional dan lokal yang telah hidup beratus tahun di Minangkabau akibatnya terjadilah defisit demokrasi di Minangkabau (Zetra Aidinil, 2015).

Dalam perkembangannya di Minangkabau lahir organisasi Niniak Mamak, Lembaga Kerapatan Adat Alam Minangkabau (LKAAM), yang menjadi wadah penghubung antara masyarakat adat Minangkabau dengan pemerintah daerah. LKAAM bisa dikatakan menjadi salah satu antithesis dari demokrasi liberal yang berkembang di Indonesia sampai saat ini. Antithesis ini sejalan dengan konsep defisit demokrasi yang berkembang di Indonesia. Salah satu indikator dari defisit demokrasi adalah menurunnya partisipasi politik masyarakat. Masyarakat secara umum mulai enggan mamasuki kegiatan politik dan aktivitas di ranah publik, serta mulai tidak peduli dengan berbagai permasalahan sosial yang dialami oleh masyarakat. Warga masyarakat mulai tidak tertarik berpartisipasi dalam urusan publik (Zetra Aidinil, 2015) Akibatnya bukan hanya berdampak buruk terhadap kelangsungan hidup bangsa tapi juga berpengaruh terhada rendahnya legitimasi tatanan politik yang ada. Gejala yang muncul adalah tingkat partisipasi masyarakat dalam pemilu terus menurun dari tahun 1999

Jurnal Socius: Journal of Sociology Research and Education Vol. 6, No.2, Th. 2019 
sampai 2014. Tahun 2014 tercatat tingkat pertisipasi berada pada tingkat paling bawah dalam sejarah pemilu Indonesia. Pada Pemilu 2014 lalu hanya 52,63\% tingkat partisipasi kota Bukittinggi (Data KPU Kota Bukittinggi 2014), dan tingkat partisipasi Kota Padang hanya 52\% (Data KPU Kota Padang 2014).

Praktek demokrasi di Indonesia saat ini termasuk di Sumatera Barat ternyata berdampak serius terhadap terjadinya erosi aktivitas politik dan kapasitas kewarganegaraan (Zetra Aidinil, 2015). Hal ini didukung berdasarkan data dari Badan Pusat Statistik (BPS) tentang indeks demokrasi di Sumatera Barat sampai tahun 2015 dapat disimpulkan bahwa bangunan demokrasi di daerah semakin melemah. Demokrasi tidak memiliki landasan terpentingnya, yaitu perwakilan politik. Kinerja lembaga perwakilan politik masuk kategori buruk. Meskipun demokrasi prosedural mengalami berbagai perbaikan seperti kualitas penyelenggaraan pemilu dari satu pemilu ke pemilu lainnya, kebebasan mendirikan partai politik, dan hak-hak warga negara untuk berpartisipasi di dalam pemilu melalui jalur non-partai juga dijamin, namun demokratisasi seperti itu ternyata tidak menjamin terwakilinya kepentingan rakyat di dalam proses-proses politik yang demokratis (Zetra Aidinil, 2015).

Sementara itu partisipasi politik dalam bentuk yang lain dari masyarakat di Provinsi Sumatera Barat dapat dilihat pada tabel berikut:

\section{Tabel 1. Tingkat Partisipasi Politik Masyarakat Sumatera Barat}

\begin{tabular}{llcc}
\hline No & \multicolumn{1}{c}{ Bentuk Pertisipasi Politik } & Derajat & Nilai \\
\hline 1. & Menjadi pemimpin publik atau pemimpin partai politik & Sangat rendah & 1,07 \\
\hline 2. & Memberi sumbangan keuangan parpol atau calon peserta pemilu & Sangat Rendah & 1,05 \\
\hline 3. & Menjadi penyelenggara pemilu & Sangat Rendah & 1,37 \\
\hline 4. & Menghadiri kampanye pemilu/pilkada & Sangat Rendah & 1,68 \\
\hline 5. & Menghadiri Pertemuan Partai & Sangat Rendah & 1,19 \\
\hline 6. & Aktif sebagai anggota partai & Sangat Rendah & 1,16 \\
\hline 7. & Mengajak orang lain mendukung salah satu partai & Sangat Rendah & 1,32 \\
\hline 8. & Berminat menjadi anggota kaukus dan menyusun strategi pertemuan & Sangat Rendah & 1,08 \\
\hline 9. & Menghadiri Pertemuan Politik & Sangat Rendah & 1,19 \\
\hline 10. & Menghubungi pejabat pemerintah atau pimpinan politik & Sangat Rendah & 1,13 \\
\hline 11. & Memasang stiker partai/calon tertentu di kendaraan pribadi & Sangat Rendah & 1.20 \\
\hline 12. & Melaksanakan diskusi-diskusi politik & Sangat Rendah & 1,19 \\
\hline 13. & Mencoblos dalam pemilu/pilkada & Tinggi & 4,2 \\
\hline 14. & Menyatakan diri mendukung partai/calon tertentu dlm pemilu/pilkada & Sangat Rendah & 1,47 \\
\hline
\end{tabular}

(Sumber: Aidinil, 2015)

Dari hasil penelitian Aidinil di atas dapat dikatakan bahwa telah terjadi defisit demokrasi di Sumatera Barat. Hal ini tentu perlu segera diatasi. Jika tidak, defisit demokrasi di Sumatera Barat akan semakin parah. Beberapa sarjana mengemukakan bahwa demokrasi deliberatif merupakan obat untuk penyakit defisit demokrasi kontemporer saat ini. (Benhabib 1996; Elster, 1998; Fung and Wright, 2003; Gutmann dan Thompson, 1996; Habermas, 1989; Michelman, 1988). Para pendukung teori ini menegaskan bahwa demokrasi deliberatif lebih dapat menjamin adanya akuntabilitas dan pemberian pelayanan publik yang berkualitas dan menghasilkan kebijakan publik yang lebih baik sekaligus membalikkan kecenderungan penurunan partisipasi politik dan erosi kewarganegaraan di kalangan masyarakat sipil. Argumennya adalah bahwa sifat dan karakteristik demokrasi deliberatif memiliki nilai instrumental dan intrinsik. Nilai instrumental demokrasi deliberatif memungkinkan ia menyelesaikan masalah tata kelola pemerintahan modern dengan lebih baik, sementara nilai 
intrinsiknya memungkinkan ia menghasilkan warga negara yang lebih baik dan lebih mampu berpartisipasi dalam politik.

Pada penelitian ini peneliti berasumsi bahwa pada tingkatan yang lebih rendah dalam bernegara konsep demokrasi deliberatif bisa menjadi solusi dalam menghadapi fenomena menurunnya tingkat pertisipasi politik masyarakat, maka yang menjadi pertanyaan penelitian adalah bagaimana proses demokrasi deliberatif pada masyarakat Minangkabau.

Tujuan penelitian ini adalah, pertama, untuk mendeskripsikan konsep demokrasi deliberatif yang dipraktekan di masyarakat Minangkabau. Seelah mendeskripsika praktek demokrasi deliberatif di Minangkabau, tujuan kedua adalah untuk mengkonsepkan demokrasi deliberatif pada Masyarakat Minangkabu. Serta manfaat penelitian ini diharapkan bisa dan mampu meberikan masukan dalam kajian disiplin soiologi, ilmu politik, dan antropologi serta mampu melengkapi analisis yang sudah dilakukan para ahli sebelumnya.

\section{Metode Penelitian}

Penelitian ini menggunakan metode kualitatif. Penelitian kualitatif dimulai dengan asumsi dan penggunaan kerangka penafsiran/teoretis yang membentuk atau mempengaruhi studi tentang permasalahan riset yang terkait dengan makna yang dikenakan oleh individu atau kelompok pada suatu permasalahan sosial atau manusia. Laporan atau presentasi tertulis akhir mencakup berbagai suara dari para partisipan, refleksivitas dari peneliti, deskripsi dan interpretasi tentang masalah penelitian, dan kontribusi pada literatur atau seruan bagi perubahan (Creswell, J, 2015). Penelitian ini menggunakan pendekatan kualitatif deskriptif karena masalah penelitian terkait dengan perilaku individu atau kelompok dalam masyarakat yang perlu dieksplorasi. Dalam hal ini peneliti mengumpulkan informasi mengenai realitas sosial dari sudut pandang aktor (Afrizal, 2016)

Penelitian ini berlokasi di Kota Solok. Alasan pemilihan kota Solok sebagai lokasi penelitian karena Kota Solok merupakan salah satu daerah yang lembaga adatnya khususnya LKAAM yang partisipasi politiknya tergolong tinggi seperti kegiatan Musyawarah Nagari dan menjadi lembaga yang sering diajak berdiskusi oleh pemerintah daerah Kota Solok sebelum merumuskan kebijakan (MUSPIDA PLUS). LKAAM Kota Solok mewakili 15 suku yang ada di Kota Solok dan kelompok masyarakat perantau yang merantau ke Kota Solok. LKAAM Kota Solok merupakan institusi adat yang berada di bawah naungan dari LKAAM Provinsi Sumatera Barat. Peneliti memahami bahwa untuk menganalisis demokrasi deliberatif di Minangkabau maka subjek penelitian harus terkait dengan Lembaga adat Minangkabau. Untuk itu unit analisis yang menjadi fokus peneliti adalah institusi LKAAM Kota Solok.

Dalam pemilihan informan penelitian ini menggunakan teknik purposive sampling yaitu informan ditentukan secara sengaja oleh peneliti. Dalam penelitian ini informan dibedakan menjadi dua yaitu informan kunci dan informan pelaku. Meskipun informan dibagi atas dua pembagian, juga terdapat informan sebagai pelaku sekaligus sebagai saksi dari peristiwa. Informan kunci dan informan pelaku dalam penelitian ini adalah Ketua LKAAM Kota Solok, Sekretaris LKAAM Kota Solok, Bendahara LKAAM Kota Solok. Informan kunci pada penelitian ini adalah anggota yang aktif ketika musyawarah.

\section{Tabel 2. Informan Penelitian}

\begin{tabular}{lll}
\hline No. & Unsur & \multicolumn{1}{c}{ Status/Jabatan } \\
\hline 1. & LKAAM Kota Solok & Ketua \\
& & Sekretaris \\
& Anggota yang sering aktif ketika muyawarah. \\
\hline
\end{tabular}


Setelah proses pemilihan informan secara purposive ini selesai, peneliti melakukan kegiatan menemui informan untuk mengumpulkan data yang dibutuhkan. Proses pertama yang peneliti lakukan adalah menghubungi Hj. Rusli, Ketua LKAAM Kota Solok.

Dalam penelitian ini, teknik pengumpulan data menggunakan Teknik wawancara. Teknik wawancara yang digunakan adalah wawancara mendalam (indepth interview) dan wawancara tidak terstruktur. Wawancara tidak terstruktur maksudnya adalah informan tidak mendalami informasi dan cukup dengan satu kali wawancara. Wawancara mendalam merupakan teknik pengumpulan data yang digunakan peneliti untuk mendapatkan keterangan-keterangan lisan melalui percakapan dan tanya jawab dengan informan secara berulang-ulang sampai peneliti meyakini data yang dibutuhkan sudah didapatkan (Afrizal, 2016). Wawancara mendalam dilakukan kepada informan pelaku (Ketua LKAAM Kota Solok), sedangkan wawancara tidak terstruktur dilakukan kepada informan kunci (sekretaris, bendahara, anggota LKAAM Kota Solok yang aktif dalam muyawarah). Pengulangan wawancara peneliti lakukan dengan maksud menggali lebih dalam terhadap temuan-temuan dari informan kunci.

Selain menggunakan teknik wawancara penelitian ini juga mengumpulkan dan menganalisa dokumen yang terkait dengan topik penelitian. Pengumpulan dokumen merupakan salah satu teknik dalam pengumpulan data kualitatif. Dokumen yang dikumpulkan bisa berupa dokumen publik (koran, makalah, laporan kantor) atau dokumen privat (Buku harian, surat, email) (Creswell, J. 2015). Pengumpulan dokumen dalam penelitian ini dilakukan dengan tujuan agar memperoleh data yang valid tentang topik yang diteliti. Pengumpulan dokumen yang dimaksud adalah dokumen yang bersifat publik yaitu laporan kegiatan LKAAM Kota Solok dan dokumen privat yaitu surat atau catatan pribadi ketua LKAAM Kota Solok.

Validitas penelitian ini menggunakan teknik triangulasi. Triangulasi dilakukan untuk memperkuat data, untuk membuat peneliti yakin terhadap kebenaran dan kelengkapan data (Afrizal.2016). Triangulasi berarti adanya informan-informan yang berbeda atau adanya sumber data yang berbeda mengenai sesuatu. Triangulasi yang peneliti lakukan dalam mengumpulkan data dengan cara mewawancarai informan yang tidak terlibat secara langsung dalam proses musyawarah LKAAM Kota Solok, namun memiliki keterkaitan dengan data yang diperoleh dari informan penelitian. Informan triangulasi yang peneliti maksud adalah LKAAM Provinsi Sumatera Barat, dan akademisi yang pernah melakukan penelitian ditempat yang sama, yaitu pengajar di Universitas Andalas.

\section{Tabel 3. Informan Triangulasi}

\begin{tabular}{lll}
\hline No. & \multicolumn{1}{c}{ Nama } & \multicolumn{1}{c}{ Status/Jabatan } \\
\hline 1. & M. Sayuti Dt. Rajo Penghulu & LKAAM Sumatera Barat \\
\hline 2. & Prof. Dr. Melinda Noer M.Sc & Dosen dan Peneliti LKAAM \\
\hline
\end{tabular}

\section{Hasil dan Pembahasan}

\section{Hasil Penelitian}

Pada bagian ini peneliti akan mendeskripsikan pelaksanaan prinsip demokrasi deliberatif masyarakat Minangkabau dilihat dari peran LKAAM kota Solok sebagai institusi masyarakat adat yang menjembatani antara masyarakat adat dengan pemerintah. 


\section{Bentuk-bentuk Penerapan Prinsip Demokrasi Deliberatif yang dilakukan oleh LKAAM Kota Solok}

Menurut James S. Fishkin dalam tulisannya yang berjudul "Pluralism, Diversity, and Deliberation Deliberative Democracy" pada jurnal "The Blackwell Guide To Social And Political Philosophy" mengatakan bahwa diskusi tentang demokrasi deliberatif pada era modern ini meliputi 3 prinsip, antara lain: deliberasi, kesetaraan politik, dan non-tirani (usaha untuk mengcegah tirani mayoritas) (J. Fishkin, 2008). Pertama, Deliberasi atau Filter bisa diartikan sebagai proses musyawarah melalui representasi dalam diskusi tatap muka yang memungkinkan lahirnya pertimbangan penilaian tentang masalah publik. Demokrasi deliberatif tidak akan mungkin dicapai apabila dalam konteks sosial terlalu banyak orang yang terlibat didalamnya atau jika motivasi dari peserta teralihkan oleh keinginan atau kepentingan yang menginginkan munculnya faksi-faksi. (J. Fishkin, 2008).

Kedua, Kesetaraan politik atau mirror. Gagasan representasi "kaca" sebagai bentuk ekspresi dari keadilan dan kesetaraan. Gambaran dari teori kaca ini adalah bagaimana publik berkumpul dan mengambil keputusan yang semua pilihan mereka setara satu sama lain. Akan tetapi kesulitannya dari pandangan demokrasi deliberatif seluruh masyarakat suatu bangsa tidak bisa berkumpul secara bersamaan untuk tujuan melakukan musyawarah. Sementara itu mereka bisa voting yang masing-masing pilihannya yang setara secara politik daripada berkumpul secara bersamaan dan harus diskusi tatap muka untuk mengambil keputusan. Perbedaan antara kedua pandaganan di atas adalah filter melihat demokrasi deliberatif sebagai sesuatu yang bisa dimurnikan dan dekembangkan kedepannya sedangkan Miror melihat demokrasi deliberatif dari perspektif yang sedang terjadi pada saat sekarang.

Ketiga, partisipasi massa/non-tirani mayoritas. Menurut Fishkin dalam jurnal "The Blackwell Guide to Social and Political Philosophy", pada kasus ini pendapat deliberatif publik merupakan "ketenangan dan deliberasi akal sehat komunitas" akan terhina oleh keinginan dan kepentingan yang memotivasi faksi atau kelompok. Pendapat pendahulu mengatakan bahwa apabila opini publik disaring dengan proses deliberatif maka akan melayani kepentingan publik dan mencagah jenis perilaku kerumunan massa yang merupakan ancaman tirani dari mayoritas. Motivasi dari deliberasi ini adalah untuk mencegah tirani dari mayoritas. Namun disisi lain strategi deliberatif ini berdampak pada kesetaraan politik, artinya strategi ini tidak melibatkan konsultasi dengan masyarakat banyak.

\section{Proses Musyawarah}

LKAAM Kota Solok merupakan organisasi non pemerintah yang rutin melakukan musyawarah setiap bulannya. Musyawarah bulanan ini masuk ke dalam kegiatan rutin tahunan. selain itu terdapat juga rapat-rapat rutin dengan institusi lain seperti institusi pemerintah, instisusi adat, gabungan institusi adat dan institusi pemerintah. Rapat bulanan dengan anggota LKAAM biasanya diadakan pada akhir minggu pada minggu pertama tiap bulannya (Laporan Kegiatan Tahunan LKAAM Kota Solok periode 2019-2023. 2019). Rapat biasanya berlokasi di kantor LKAAM Kota Solok, Nagari Lubuak Sikarah, Kota Solok. Lokasi kantor LKAAM Kota Solok satu komplek dengan Mesjid Lubuak Sikarah, Kota Solok.

Rapat rutin bulanan ini mengundang semua anggota LKAAM Kota Solok yang berjumlah 32 orang yang terdiri dari satu orang ketua, satu orang wakil ketua, satu orang sekretaris, satu orang bendahara dan 28 orang anggota. Masing-masing anggota mewakili sukusuku dan kelompok-kelompok masyarakat yang ada di Kota Solok. Anggota LKAAM Kota Solok mewaiki 15 suku-suku dan beberapa kelompok perantau yang sudah lama menetap di Kota Solok.

Musyawarah biasanya dipimpin oleh Ketua LKAAM Kota Solok Rusli Chatib Sulaiman, dan apabila ketua berhalangan untuk hadir maka rapat dipimpin oleh wakil ketua LKAAM Kota Solok. Rapat rutin bulanan tujuannya untuk musyawarah konsolidasi tiap-tiap 
anggota LKAAM. Setelah konsolidasi dilakukan biasanya rapat dilanjutkan dengan membahas masalah-masalah atau isu-isu yang berkembang di masyarakat Kota Solok. Masalah-masalah dan isu-isu tidak hanya seputar hal yang berkaitan dengan adat dan budaya saja namun juga berkaitan dengan kehidupan sosial, ekonomi, dan politik. Salah satu isu dan masalah yang didiskusikan ketika rapat seperti isu kenakalan remaja di Kota Solok.

LKAAM sebagai institusi masyarakat adat bertujuan menjamin kelangsungan adat basandi sarak, sarak basandi kitabullah di Kota Solok. Untuk menjamin ABS/SBK perlu generasi muda yang terdidik. Baa ka tapaliharo adaik kalau anak mudonyo indak berpendidikan, suko cabut sakolah. Cafe-cafe yang jadi tampek cabut anak sakolah tu paralu dicabuik ijin cafenyo, bia indak manjadi tampek anak sakolah cabut. (Data primer. 2019)

Salah satu hasil musyawarah yang dilakukan oleh LKAAM Kota Solok dijadikan masukan untuk pemerintah Kota Solok dan dijadikan kebijakan. Ijin café di Kota Solok disosialisaikan dan dilakukan penertiban apabila terjadi pelanggaran. LKAAM Kota Solok didampingi dengan aparatur pemerintah Kota Solok (Satuan Polisi Pamong Praja) melakuka razia ijin café-café dan melakukan penindakan jika ada pelanggaran.

\section{Pemilihan Ketua Menggunakan Konsep Demokrasi Deliberatif}

Apabila demokrasi dikelompokan berdasarkan pemilihan pemimpin maka demokrasi bisa dipisahkan menjadi demokrasi liberal dan demokrasi deliberatif. Demokrasi liberal yang muaranya memilih pemimpin dengan cara voting karena kesetaraan politik sangat dijunjung tinggi. Sementara demokrasi deliberatif menekankan pada pemberian kewenangan kepada orang lain untuk mewakili masing-masing individu atau kelompok dalam masyarakat untuk bermusyawarah dan bermufakat dalam memilih pemimpin.

Dalam pemilihan Ketua LKAAM Kota Solok setiap orang diberi kesempatan yang sama untuk mencalonkan diri menjadi ketua. Apabila calon ketua lebih dari satu maka akan dilakukan voting. Pada pemilihan ketua periode 2019-2023 hanya satu orang calon yang mencalonkan diri. Calon merupakan incumbent yang menjabat periode sebelumnya. Hal ini seperti ada kesepakan secara tidak tertulis diantara pemegang suara bahwa calon yang terpilih sekarang merupakan sosok yang pas dalam memimpin organisasi masyarakat adat Kota Solok periode selanjutnya.

Ketua LKAAM Kota Solok dua periode ini merupakan sosok yang diangap sebagai sosok pengayom dalam masyarakat. Beliau dipanggil dengan panggilan "Ayah" oleh masyarakat sekitar. Ini merupakan bentuk apresiasi dari masyarakat kepada sosok Ketua LKAAM Kota Solok. Dilihat dari latar belakang beliau merupakan sosok yang sering mengepalai institusiinstitusi penting. Sebelumnya beliau pernah menjabat sebagai ketua MUI Kota Solok 5 periode, kemudian menjabat sebagai Ketua KAN Kota Solok 4 periode. Ketelitian beliau dalam memimpin organisasi masyarakat sudah teruji serta kinerja beliau mendapatkan apresiasi dari masyarakat dan termasuk oleh LKAAM Propinsi Sumatera Barat sebagai LKAAM teraktif.

\section{Representasi Kelompok Masyarakat}

LKAAM merupakan organisasi non pemerintah yang merupakan penghubung antara masyarakat adat dengan pemerintah. LKAAM diisi oleh Niniak Mamak dan pemangku adat yang salah satu tujuan dan fungsinya adalah menggalang partisipasi masyarakat untuk mensukseskan pembangunan daerah dalam rangka pembangunan nasional secara bersamasama, serta wadah penampung aspirasi (AD/ART LKAAM Sumatera Barat. 2018).

LKAAM Kota Solok diisi oleh anggota yang merupakan Niniak Mamak dan pemangku adat yang memilik latarbelakang pekerjaan yang berbeda-beda. Ada yang bekerja sebagai pedagang dan petani ada juga yang bekerja di institusi pemerintah (PNS) dan anggota legislatif. Perbedaan latar belakang pekerjaan ini membuat anggota LKAAM bisa berinteraksi denga lapisan masyarakat yang berbeda. Salah satu ide dan gagasan yang datang dari masyarakat Kota

Jurnal Socius: Journal of Sociology Research and Education Vol. 6, No.2, Th. 2019 
Solok melalui LKAAM Kota Solok adalah pembangunan taman kota di pusat kota Solok. Kebutuhan akan Ruang Terbuka Hijau (RTH) oleh masyarakat Kota Solok disampaikan oleh LKAAM Kota Solok kepada pemerintah daerah dan ditanggapi dengan dibukanya taman kota ini. Karena taman kota ini diinisiasi oleh LKAAM maka nama dari taman kota diusulkan oleh Ketua LKAAM Kota Solok.

Salah satu cara yang unik dilakukan oleh Ketua LKAAM Kota Solok untuk menjemput aspirasi masyarakat adalah dengan menggunakan moda transportasi umum di Kota Solok, salah satunya ojek. Satu-satunya ketua LKAAM di Sumbar yang diberi fasilitas kendaraan operasional hanya LKAAM Kota Solok. Tapi Ambo pribadi lebih suka pakai ojek. Tujuannya agar masyarakat masih bisa melihat secara langsung kalau "ayah" masih sehat dan beraktifitas normal. Selain itu apabila ada masyarakat yang mau ngobrol bisa langsung, kalau pakai mobil tidak kelihatan sama masyarakat. (Data primer. 2019)

Hal lain yang menjadi nilai tambah dari organisasi LKAAM ini adalah sosok ketua yang ketokohannya menonjol di masyarakat. Sapaan akrab "Ayah" yang diberikan masyarakat merupakan bentuk kedekatan antara masyarakat dengan ketua LKAAM Kota Solok. Dengan kedekatan ini fungsi LKAAM sebagai lembaga yang menjembatani antara masyarakat adat dengan pemerintah bisa teracapai. Ini dibuktikan dengan kebijakan ijin café yang diterbitkan oleh pemerintah Kota Solok merupakan masukan dari LKAAM Kota Solok yang bertujuan untuk menekan angka kenakalan remaja seperti bolos pada jam pelajaran sekolah.

\section{Pembahasan}

\section{Prinsip Deliberasi}

Fishkin dalam bukunya "When People Speak: Deliberatives Democracy and Public Consultation" (2009) mengatakan demokrasi deliberatif sebenarnya mengenai menanyakan kehendak politik bersama mengenai apa yang harus diselesaikan (J. S. Fishkin, 2009). Hal ini mengenai pengambilan sudut pandang yang mewakili kolektif, penjelasan persetujuan. Fishkin menjelaskan bahwa dalam pengambilan keputusan semisal kebijakan publik perlu masyarakat perlu dimintai pendapat dan diajak bermusyawarah untuk memutuskan sesuatu kebijakan, bukan hanya dimintai persetujuan yang mengenai "iya" atau "tidak". Proses meminta pesetujuan harus dibarengi dengan penjelasan kenapa setuju kenapa tidak setuju. Kepemilikan informasi mengenai sebuah isu kebijakan yang akan diambil pemerintah perlu diberikan kepada masyarakat. Perlu membagikan diskusi dengan publik mengenai implikasi kepada kita semua (J. S. Fishkin, 2009). Apa yang dikatakan Fishkin mengenai prinsip deliberasi yang menekankan pada 5 aspek agar kualitas deliberasi proses dapat terukur. 5 aspek tersebut adalah informasi, keseimbangan substansi, perbedaan keterwakilan, menggunakan hati nurani, dan terakhir pertimbangan yang setara. Dilihat dari fenomena pelaksaaan prinsip demokrasi deliberatif yang dilakukan LKAAM Kota Solo bisa dilihat pada penjelasan berikut.

\section{Bukak Kulik Nampak Isi}

Setiap orang diberikan akses yang akurat terhadap informasi yang mereka percayai relevan terhadap isu yang dibicarakan. Rapat konsolidasi yang dilakukan LKAAM Kota Solok sejalan dengan apa yang dikatakan Fishkin mengenai informasi yang akurat terhadap sesuatu isu. Pada rapat konsolidasi setiap anggota diberi kesempatan untuk berbicara mengenai isu-isu yang dianggap penting. Setiap isu yang diangap penting dibarengi dengan pemberian pendapat oleh masing-masing anggota yang merasa memiliki informasi lebih mengenai isu sehingga informasi yang dimiliki oleh anggota terbagi secara merata dan dapat diolah yang kemudian berupa output rapat yang dicatat sekretaris rapat yang nantinya bisa diteruskan kepada pemerintah atau masyarakat. 
Pada setiap rapat Ketua membuka rapat, kemudian menginformasikan mengenai suratsurat yang masuk, surat keluar selama sebulan belakang kepada atau oleh LKAAM Kota Solok. Kemudian rapat dilanjutkan dengan pemberitahuan laporan kegiatan selama sebulan kebelakang. Pemberitahuan ini jika ditelaah menggunakan teori Fishkin merupakan suatu bentuk perilaku yang dilakukan oleh Ketua LKAAM Kota Solok agar informasi yang dimiliki oleh masing-masing anggota sama, berimbang dan akurat tujuannya agar tidak terjadi salah informasi. Dengan informasi yang merata mengenai suatu isu maka diskusi mengenai suatu isu bisa berjalan baik. Setiap anggota bisa memberikan pendapat dari sudut pandang masingmasing.

\section{Sakato Mako Batuah}

Argumen yang disampaikan oleh seseorang atau satu perskeptif mendapatkan jawaban dari perspektif yang lain sehingga tercipta keseimbangan substansi pada hasil rapat. Mekanisme rapat yang terbuka dan kesetaraan dalam bependapat seperti yang tertuang dalam falsafah Minangkabau "tagak samo tinggi, duduak samo randah" dalam rapat LKAAM Kota Solok sejalan dengan konsep keseimbangan substansi yang dibicarakan Fishkin. Setiap isu yang dilempar ke forum musyawarah oleh ketua LKAAM Kota Solok selalu diberikan tanggapan atau masukan oleh anggota musyawarah. Pada saat rapat yang membahas mengenai ijin bangunan liar yang ada di Kota Solok beberapa pendapat yang muncul dari anggota musyawarah, diantaranya; (1) Rizal Sr. Dt. Bandaro (Bendahara LKAAM Kota Solok) yang menanggapi soal birokrasi yang panjang dan berbelit-beli mengenai ijin bangunan. Serta tidak singkron antara Satuan Polisi Pamong Praja Kota Solok dan Dinas Tata Kota Kota Solok, dan (2) Amrizal (Anggota LKAAM Kota Solok) yang menambahkan mengenai prosedur ijin bangunan serta kualitas kinerja aparatur yang tidak mengetahui batas antara wilayah Kota Solok dan Kabupaten Solok sehinga masyarakat sekitaran perbatasan mengalami kebingungan untuk mengurus ke wilayah pemerintahan mana.

Mekanisme saling memberikan masukan dari sudut pandang masing-masing ini merupakan bentuk penyeimbang substansi rapat sehingga output yang nanti menjadi masukan untuk pemerintah Kota Solok dari LKAAM Kota Solok bisa berasal dari sudut pandang yang lebih luas dan lebih seimbang.

\section{Latakan Sasuatu Pado Tampeknyo}

Perbedaan disini diartikan Fishkin sebagai posisi-posisi penting di dalam masyarakat diwakili oleh niniak mamak yang menjadi anggoa LKAAM dan aktif menjadi peserta musyawarah. LKAAM Kota Solok merupakan organisasi non pemerintah yang merupakan representasi dari masyarakat adat (AD/ART LKAAM Provinsi Sumatera Barat. 2018). Dalam konteks ini LKAAM Kota Solok diisi oleh 15 Suku yang ada di Kota Solok dan perwakilan perantau yang sudah lama menetap di Kota Solok. Keterwakilan masing masing kelompok masyarakat adat dan masyarakat umum tergabung dalam LKAAM Kota Solok secara penuh.

\section{Lamak Dek Awak Katuju Dek Urang}

Fishkin mengartikannya sebagai keinginan untuk mendengarkan dan mempertimbangkan argumen. Pada saat penelitian, peneliti belum pernah melihat ada perbedaan pendapat yang menjurus kepada konflik dalam musyawarah. Masing-masing anggota peserta rapat memberikan masukan dari sudut pandang masing-masing tanpa memaksa untuk pendapat diterima. Berdasarkan diskusi peneliti dengan Ketua LKAAM Kota Solok, Bendahara LKAAM Kota Solok dan beberapa anggota LKAAM Kota Solok belum pernah terjadi pemaksaan pendapat yang menuju kearah konflik selama musyawarah digelar. Setiap anggota yang berpendapat bersedia mendengarkan pendapat anggota lain. Peneliti melihat ini 
disebabkan karena organisasi ini merupakan organisasi yang mewakili masyarakat adat maka ini diisi oleh para Niniak Mamak dan pemangku adat.

Tujuan dari LKAAM dibentuk adalah untuk melestarikan adat (AD/ART LKAAM Provinsi Sumatera Barat. 2018). Jadi motivasi utama agar ABS/SBK tetap lestari sampai generasi-generasi berikutnya. Dengan motivasi yang sama ini maka konflik kepentingan masing-masing individu di dalam LKAAM Kota Solok cendrung tereduksi oleh motivasi utama.

\section{Manimbang Samo Barek Maukua Samo Panjang}

Pendapat-pendapat yang diberikan oleh peserta dipertimbangkan berdasarkan kemampuan terlepas dari peserta mana yang menawarkan. Pendapat ini dipertimbangkan bukan karena posisi sosial dalam masyarakat tetapi alasan pendapat tersebut diberikan. Hasil pengamatan yang peneliti lakukan selama proses musyawarah yang dilakukan LKAAM Kota Solok ketua sebagai pimpinan rapat memberikan informasi-informasi yang penting untuk diberikan agar setiap anggota musyawarah bisa memberikan pendapat. Setiap pendapat ditampung oleh pimpinan rapat dan dibuat notulensi rapat yang dilakukan oleh sekretaris LKAAM Kota Solok. Setiap pendapat dihargai sama terlepas dari siapa yang berbicara karena hampir semua anggota LKAAM Kota Solok yang ikut rapat merupakan Niniak Mamak dan Pemuka Adat ataupun tokoh masyarakat. Status sosial yang sama dari masing-masing anggota menjadikan forum musyawarah ini menjadi berimbang, kedudukan salah satu anggota tidak lebih tinggi dari anggota lainnya.

Menurut peneliti hal ini juga dipengaruhi oleh sosok Ketua LKAAM Kota Solok yang memberikan fasilitas dan ruang yang sama kepada masing-masing anggota. Jabatan di dalam organisasi tidak mempengaruhi kekuatan pendapat seseorang namun substansi apa yang disampaikan merupakan hal yang lebih penting.

Kualitas dari proses deliberasi pada forum musyawarah LKAAM Kota Solok ini bisa berjalan dengan seimbang. Kelima kriteria ini sepenuhnya terlaksana ketika muyawarah rutin dilakukan. Informasi yang diberikan kepada masing-masing anggota relevan dengan isu yang sedang berkembang di masyarakat Kota Solok. Setiap perspektif yang disampaikan pada saat musyawarah berlangsung mendapat tanggapan dari perspektif lain dan pada kasus ini perspektif yang lain cendrung menambahkan atau menguatkan. Keterwakilan dari setiap kelompok suku, kelompok masyarakat terwakilkan dalam organisasi LKAAM Kota Solok. Kesediaan untuk mendengarkan pendapat anggota lain yang lebih baik, serta kesetaraan dalam berpendapat yang tidak dipengaruhi oleh status sosial yang memberikan pendapat tetapi apa konteks yang disampaikan juga terpenuhi selama pengamatan peneliti di lapangan.

\section{Prinsip Kesetaraan Politik}

Fishkin menganggap deliberatif demokrasi sebagai kombinasi antara kesetaraan politik dan deliberasi. Gagasan dasar dari kesetaraan politik adalah kesetaraan pertimbangan dari preferensi politik. Artinya preferensi masing-masing orang perlu sama untuk dianggap setara. Tolak ukurnya adalah gagasan dari kesetaraan kekuatan suara (Equal voting power) (J. S. Fishkin, 2009).

Dalam bukunya yang berjudul When People Speak (2009) Fishkin mengatakan equal voting power diartikan dalam bentuk equal decisive voter. Decisive voter pada gagasan dasarnya dikelompokan dalam 2 bentuk yaitu, pertama, semua pemilih memilih dan setiap suara dihitung setara satu dengan yang lainnya sehingga setiap orang memiliki kesearaaan dalam memutuskan sesuatu. Yang kedua setiap pemilih memilih sebuah "microcosm" dan "microcosm" memilih yang kemudian suara masing-masing dihitung setara. Pada bentuk pertama Fishkin mengatakan setiap suara dihitung setara namun sering terjadi perilaku abai karena satu suara berskala kecil dalam ruang lingkup keputusan. Pada bentuk kedua masing- 
masing suara memiliki peran yang besar dalam menentukan keputusan, dan merupakan solusi dari perilaku abai. "Microcosm" memiliki alasan untuk meberi perhatian lebih karena mereka merupaka representasi dari kelompk individu.

LKAAM merupakan organisasi yang didirikan sebagai bentuk representasi masyarakat adat, dan mejembatanai kepentingan masyarakat adat secara khusus dan masyarakat secara umum dengn pemerintah. Disamping itu tujuan LKAAM didirikan adalah sebagai alat yang membantu berjalannya pembangunan nasional dengan menjalankan pembangunan daerah (AD/ART LKAAM Sumatera Barat. 2018). LKAAM Kota Solok menjembatani kepentingan 15 Suku dan kelompok perantau di Kota Solok dengan pemerintah daerah Kota Solok. Yang menjadi perbedaan dengan konsep kesetaraan politik yang dikemukakan Fishkin adalah masyarakat adat Kota Solok tidak memilih secara langsung representatifnya di dalam LKAAM. Masing-masing suku memiliki Niniak Mamak atau Pemangku adat yang diwariskan menurut garis keturunan dari mamak turun ke kemenakan. Menurut peneliti representasi yang diberikan kepada pemangku adat berdasarkan garis kerturunan memiliki nilai lebih daripada pemberian representasi berdasarkan voting. Karena Niniak Mamak atau pemangku adat memiliki kedudukan yang tinggi secara sosial dalam masyarakat. Ketika status sosial yang dibawa oleh masing-masing Niniak Mamak dikumpulkan dalam satu organisasi maka setiap orang yang berada dalam organisasi LKAAM setara secara status sosial.

Sumatera Barat khususnya Kota Solok masih terkenal dengan masyarakatnya yang bepegang teguh kepada adat Minangkabau. Posisi Niniak Mamak sebagai kepala adat masih sangat dihargai secara politik, sehingga organisasi LKAAM sebagai representasi masyarakat adat yang didalamnya diisi oleh para Niniak Mamak memiliki kekuatan politik yang cukup besar untuk mempengaruhi kebijakan yang dibuat oleh pemerintah daerah. LKAAM Kota Solok merupakan LKAAM yang paling aktif di Sumatera Barat (Data primer.2019). Berdasarkan data laporan kegiatan tahun 2018 LKAAM Kota Solok 264 kali melakukan kegiatan. Kegiatan berupa rapat rutin tiap bulan, rapat dengan pemerintah daerah Kota Solok, MUSPIDA, dan menjadi tim pertimbangan penilaian kinerja OPD Kota Solok. Tingkat keaktifan yang tinggi dalam mengontrol kebijakan pembangunan pemerintah Kota Solok membuat LKAAM mendapatkan posisi tawar yang tinggi secara politik. Seperti yang disampaikan ketua LKAAM Kota Solok. Ide tentang equal voting power merupakan defenisi dari kesetaraan politik (J. S. Fishkin, 2009) memiliki kecocokan dengan objek penelitian ini. LKAAM Kota Solok merupakan representasi dari masyarakat adat Kota Solok memiliki kekuatan politik yang lebih besar dalam mempengaruhi kebijakan pemerintah daerah Kota Solok.

\section{Prinsip Partisipasi}

Partisipasi yang dikatakan Fishkin adalah partisipasi politik massa. Partisipasi ini menuntut populasi dalam jumlah besar pada partisipasi politik. Partisipasi politik yang dimaksud Fishkin adalah perilaku dari kelompok massa diarahkan oleh pengaruh, secara langsung atau tidak langsung, perumusan, adopsi, atau implementasi dari pemerintahan atau pilihan kebijakan. Voting merupakan partisipasi massa yang paling banyak diterapkan pada saat sekarang ini, namun ada bentuk lain seperti menyumbangkan uang, waktu, atau tenaga untuk mendatangkan politik, demonstrasi, menyurati pemerintah, membuat petisi juga merupakan aktivitas yang melibatkan banyak orang dan bentuk partisipasi massa (J. S. Fishkin, 2009).

Berdasarkan fenomena demokrasi deliberatif di Minangkabau, LKAAM Kota Solok berhasil menjadi representasi dari masyarakat Kota Solok secara umum. LKAAM menjadi jembatan antara pemerintah daerah Kota Solok dengan mayarakat adat Kota Solok khususnya dan Mayarakat secara umum. Namun partisipasi massa yang dibicarakan Fishkin dalam konsep pertisipasi tidak terbukti sejalan dengan fenomena demokrasi deliberatif LKAAM Kota Solok,

Jurnal Socius: Journal of Sociology Research and Education Vol. 6, No.2, Th. 2019 
hal ini disebabkan LKAAM Kota Solok merupakan lembaga non pemerintah yang bersifat sukarela yang fokus utamanya melestarikan adat di Minangkabau, adat basandi sarak, sarak basandi kitabulllah. Selain itu tujuan menjembatani antara pemerintah daerah dengan masyarakat adat tidak menjadikan LKAAM sebagai institusi yang langsung berdampingan dengan masyarakat akan tetapi menjadi titik penyeimbang antara keduanya. Berbeda dengan organisasi lain yang berdampingan langsung dengan masyarakat dan menggerakan masyarakat secara langsung untuk berpartisipasi seperti Partai Politik atau Lembaga Bantuan Hukum (LBH).

Namun fenomena demokrasi deliberatif pada masyarakat Minangkabau ini sejalan dengan pemikiran Fishkin bahwa demokrasi deliberatif bisa menjadi wadah untuk mencegah tirani mayoritas. Mencegah perilaku kelompok massa yang cenderung untuk melakukan kekerasan terhadap minoritas karena ada pengaruh atau mobilisasi, seperti yang terjadi pada awal reformasi di Indonesia. Meskipun partisipasi massa pada demokrasi deliberatif masyarakat Minangkabu tidak terjadi, Fishkin mengatakan bahwa microcosm deliberasi tidak akan bisa memfasilitasi partisipasi massa karena partisipasi massa dianggap sebagai sebuah ancaman kepada demokrasi itu sendiri. Orang-orang memiliki semangat dan kepentingan, yang mana apabila dibangkitkan, bisa memotivasi munculnya faksi, dan memotivasi perilaku yang mungkin menyakitkan terhadap hak orang lain (J. S. Fishkin, 2009).

\section{Kesimpulan}

Pelaksanaan prinsip demokrasi deliberatif di Minangkabau sesuai dengan yang dibicarakan oleh Fishkin. Dimana demokrasi deliberatif yang menurut Fiskin merupakan bentukan dari Microcsm sama dengan apa yang terjadi pada institusi adal LKAAM Kota Solok. Microcosm yang dibicarakan Fiskin merupakan bentuk kesetaraan politik yang ada di LKAAM Kota Solok. Disamping itu nilai-nilai dalam musyswarah mufakat yang dilaksanakan olek LKAAM Kota Solok sejalan dengan aspek yang menentukan kualitas deliberasi yaitu informasi, keseimbangan substansi, perbedaan keterwakilan, penggunaan hati nurani, serta pertimbangan yang setara.

Proses pelaksanaan demokrasi deliberatif di LKAAM Kota Solok berupa pemberian kewenangan (deliberasi) kepada para niniak mamak sebagai kepala suku dari masing-masing suku dan kelompok masyarakat di Kota Solok. Pemberian kewenangan ini bertujuan agar LKAAM Kota Solok bisa menjadi intitusi yang menjembatani kepentingan masyarakat adat dengan Pemerintah Kota Solok dan begitupun sebaliknya. Tujuan akhir dari LKAAM Kota Solok merupakan perwujudan dari program LKAAM Provinsi Sumatera Barat yaitu mewujudkan pembangunan nasional melalui pembangunan daerah. LKAAM Kota Solok membantu Pemerintah Daerah Kota Solok dengan semangat "bapucuak ka ateh, baurek kabawah". Informasi yang didapat dari masyarakat kemudian didiskusikan dalam sebuah musyawarah mufakat yang keluarannya nanti akan disampaikan kepada pemerintah agar membantu pemerintah dalam memformulasikan kebijakan. LKAAM Kota Solok aktif dalam membantu Pemerintah Kota Solok dalam menjalankan pembangunan daerah. Arti kata aktif membantu bukan hanya memberikan support kepada pemerintah namun juga berbentuk krtitikan terhadap apa yang dilakukan oleh pemerintah Kota Solok. Salah satu bentuk dukungan dari LKAAM Kota Solok adalah dengan membantu program Nol Angka Kemiskinan Kota Solok. Bentuk kritikan dari LKAAM Kota Solok berupa pemberian masukan kepada Walikota Solok terhadap kinerja kepala dinas atau OPD yang ada di Kota Solok. Kritikan itu dibarengi dengan pemberian saran dan solusi. 


\section{Daftar Pustaka}

Afrizal, M. (2016). Metode Penelitian Kualitatif. Depok: Rajagrafindo Persada.

Benhabib, Seyla. (1996). Toward a Deliberative Model of Democratic Legitimacy. In: S.Benhabib (Ed.), Democracy and Difference: Contesting the Boundaries of the Political , 67-94. Princeton, NJ: Princeton University Press.

Chambers, Simone (2003). Deliberative Democratic Theory. Annual Review of Political Science, 6: 307-326.

Creswell, J, W. (2015). Research Desaign: Pendekatan Kualitatif, Kuantittif, dan Mix. Yogyakarta: Pustaka Pelajar.

Cunningham, Frank (2002). Theories of Democracy: A Critical Introduction. NY:Routledge.

Elster, Jon (1998). Introduction. In: J. Elster (Ed.), Deliberative Democracy, 1-18. Cambridge, MA: Cambridge University Press.

Fung, Archon and Erik Olin Wright (eds.) (2003). Deepening Democracy: Institutional Innovations in Empowered Participatory Governance. New York, NY: Verso.

Gutmann, Amy and Dennis Thompson (2004). Why Deliberative Democracy? Princeton, NJ: Princeton University Press.

Habermas, Jürgen (1989). The Structural Transformation of the Public Sphere. Cambridge: Harvard University Press.

Macedo, Stephen, (Ed.) (1999). Deliberative Politics. New York: Oxford University Press.

Mansbridge, Jane (1980). Beyond Adversary Democracy. New York, NY: Basic Books.

Michelman, Frank (1988). Law's Republic. Yale Law Journal, 97(1): 1493-1537.

Fishkin, J. (2008). Pluralism, Diversity, and Deliberation Deliberative Democracy. The Blackwell Guide to Social and Political Philosophy.

Fishkin, J. S. (2009). When The People SPeak. Oxford: Oxford University Press.

Naim, M. (1987). Jurus Manajemen Indonesia: Sistem Pengelolaan Restoran Minang. Sebuah Prototipe Sistem Ekonomi Pancasila. Jakarta: Yayasan Obor.

Nasroen. (1954). Dasar-dasar Falsafah Hidup Minangkabau. Djakarta: Bulan Bintang.

Wimmy Haliim, (2016). Demokrasi Deliberatif Indonesia: Konsep Partisipasi Masyarakat dalam Membentuk Demokrasi dan Hukum yang Responsif. Jurnal Masyarakat Indonesia, 42 (1): 19-30.

Young, Iris Marion (2000). Inclusion and Democracy.Oxford: Oxford University Press.

Zetra Aidinil. (2015). Tingkat Kesukarelaan Politik Masyarakat Sawahlunto. Sawahlunto. KPU Sawahlunto. 